\title{
DURING WIND AND RAIN
}

THEY sing their dearest songs -

$\mathrm{He}$, she, all of them - yea,

Treble and tenor and bass,

And one to play;

With the candles mooning each face....

$\mathrm{Ah}$, no; the years $\mathrm{O}$ !

How the sick leaves reel down in throngs!

They clear the creeping moss -

Elders and juniors - aye,

Making the pathways neat

And the garden gay;

And they build a shady seat. ...

$\mathrm{Ah}$, no; the years, the years;

See, the white storm-birds wing across!

They are blithely breakfasting all -

Men and maidens - yea,

Under the summer tree,

With a glimpse of the bay,

While pet fowl come to the knee....

Ah, no; the years $\mathrm{O}$ !

And the rotten rose is ript from the wall. 